\title{
Why do the Chinese make direct investment in the Europe? Insights from disaggregated bilateral data
}

\author{
Thong Trung Nguyen ${ }^{1, *} \cdot$ Xuan Vinh Vo ${ }^{2}$ \\ ${ }^{1}$ School of Banking, University of Economics Ho Chi Minh City, Vietnam \\ ${ }^{2}$ Institute of Business Research, University of Economics Ho Chi Minh City, Vietnam
}

Received: 31 December 2020

Revised: 30 March 2021

Accepted: 30 March 2021

\begin{abstract}
This study explores the economic factors of foreign direct investment (FDI) from China to Europe. By drawing data over 8 years and dataset from the International Monetary Fund (IMF) and World Bank (WB), we found that Chinese FDI outflows to Europe are driven by the recipient country's fundamentals (trade openness, resource, institutional quality, and economic growth). These findings confirm the current literature while asserting counterintuitive facts. One of many points is that China is less likely to seek out the investment channel in the large economic status. More importantly, this study differs from extant literature by using the disaggregated panel data of bilateral FDI and trade openness. Therefore, our results would draw policy implications in terms of international finance.
\end{abstract}

Keywords: foreign direct investment; China, Europe

JEL Classification Codes: F21, F36, C22, C23

\section{Introduction}

In classical economic theory, capital flows are shifted from high-income economies to middleand low-income economies. However, poor countries have received little capital from rich countries (Lucas, 1990), and some emerging and developing economies, in contrast, invest in advanced countries. There are many studies on foreign direct investment (FDI) into Europe, but most of them are from developed countries. China is considered an emerging economy, and studies on its capital inflow into Europe are fascinating. This study primarily aims to contribute empirical evidence of disaggregated bilateral FDI from China to European economies. China typically invests in less developed countries; however, its investments in Europe are outflows from an emerging economy to advanced economies. China typically invests in less developed countries; however, its investments in Europe are outflows from an emerging economy to advanced economies.

After three decades of economic transformation, China overcame Japan to become the world's second-largest economy in 2010 (Hanemann and Huotari, 2015) with Chinese outward FDI flows booming from recent years up to $12 \%$ of world shares.

\footnotetext{
* Corresponding author. E-mail: thongnt@ueh.edu.vn.
}

Citation: Nguyen, T. T., and Vo, X. V. (2021) Why do the Chinese make direct investment in the Europe? Insights from disaggregated bilateral data, Economics and Business Letters, 10(3), 274-283.

DOI: 10.17811/ebl.10.3.2021.274-283 
Figure 1. Chinese FDI outflows.

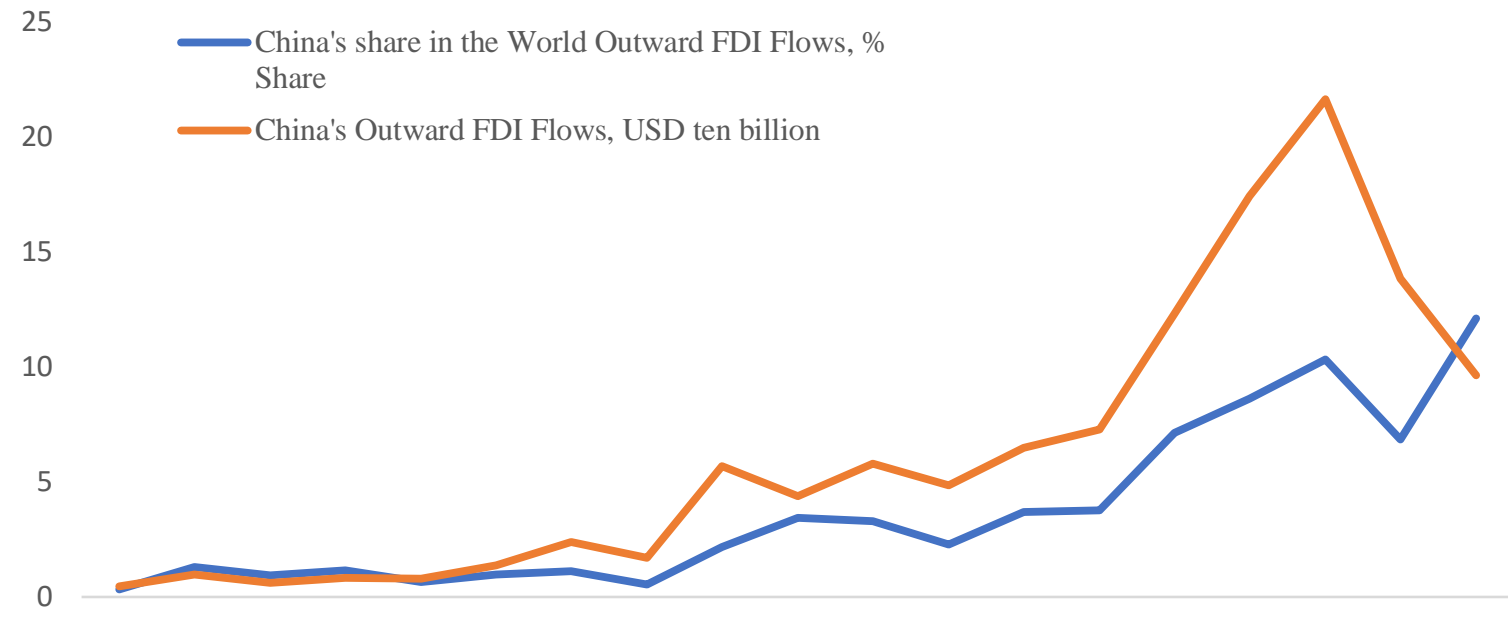

2000200120022003200420052006200720082009201020112012201320142015201620172018

Source: World Development Indicators, World Bank.

Chinese FDI is the factor that attracts attention from researchers. Figure 1 shows the number of China's share in the World Outward FDI flows that increases during 2000-2018. Comparatively, the current values of USD decreased in 2017, but in general, they are in the up-trend position.

Many papers show that FDI is supposed to be the main factor to increase economic growth (e.g., Nair-Reichert and Weinhold (2001), Choe (2003), and Faras and Ghali (2009)).

Europe, especially the European Union (EU), is one of the main destinations of inflow FDI, and the study of FDI in the EU is necessary (Villaverde and Maza, 2014). The key aspects of bilateral relations between China and Europe are the economic policy dialog promoting economic growth (Lv and Spigarelli, 2015) and the Chinese Go Global policy (Bellabona and Spigarelli, 2007). Zhang and Daly (2011) discover that gross domestic product, market size, and trade openness affect global Chinese direct investment.

This paper contributes to the literature in a few aspects. First, it contributes empirical evidence of Chinese FDI to the world. Second, it contributes to measuring bilateral data of trade openness and FDI and the relationships between them. Third, the study employs institutional quality from the World Governance Indicators (WGI) with all six indices to measure their impacts on Chines outward FDI.

By using data during 2009-2017 in the disaggregated approach, our empirical results show factors that affect Chinese outward FDI in Europe and direct investments are positively related to resources, trade openness, and institutional quality but negatively related to the Gross Domestic Product (GDP) of host countries.

These results imply that European governments attract more capital flows, especially Chinese FDI, which should enhance their macroeconomic characteristics such as resource rents, trade openness, and institutional quality. Additionally, the Chinese government should consider the GDP size of recipients.

This paper is structured as follows. Section 2 provides a literature review, Section 3 presents the models and data of bilateral FDI between Europe and China, Section 4 shows the regression results, and Section 5 provides the conclusion.

\section{Literature review}

Dunning $(1976$; 1993) supposes that host country or region's traditional determinants of FDI are market seeking, efficiency seeking, and resource/asset seeking. But traditional FDI theories 
only emphasize the investment of developed countries. Examining FDI from an emerging country like China needs more specific determinants. Buckley et al. (2007) use empirical study with panel data of Chinese FDI into 49 countries and indicate that China's outward FDI related to natural resources and poor institutional governance. Zhang and Daly (2011) quantify the positive determinants of China's outward FDI such as international trade, market size, economic growth, openness, and natural resources.

Markusen and Venables (1998) discover that the decisions of investment of Multinational Corporations (MNCs) are based on the scale of economies, transport costs, and market size by using Markusen's model, which is the centrality of our literature review. Although Li et al. (2020) contribute findings that the "One Belt, One Road" policy does not exhibit positive effects on China's outward FDI, our study differentiates by examining European economies, where the economic incentives are more appealing. Additionally, the aforementioned study only focuses on 2003-2015, whereas we look at the post-financial crisis. According to Wang et al. (2010), the main causes of bilateral trade flows in The Organisation for Economic Cooperation and Development (OECD) countries are through the estimation of increasing gravity equation, showing R\&D supply, and FDI inflows.

Bilateral trade is usually used to investigate the outward FDI between partners. Egger and Pfaffermayr (2004) investigate distance, bilateral trade, and FDI distance that affect bilateral trade and outward FDI.

Kurul (2017) applies pull and push factors to investigate the impacts of institutional quality to FDI. Also, pull factors from recipients play an important role in attracting FDI inflows, i.e., economic growth, and natural resources rents.

Blonigen (2005) finds that FDI is attracted by institutions in developing countries for different reasons. Business costs increase in countries that have low level of institutional quality, and so the inward FDI decreases. But the measurement of institutional quality is difficult because there is no exact method of survey.

Some studies use independent surveys from enterprises' feedback on political, legal, and economic quality to create a mixed index. Kaufmann et al. (2010) applied the Worldwide Governance Indicators with six variables of institutions measuring the quality of institutions in the aggregated approach in many countries with unique, comprehensive, and long-term methods.

Focusing on the size of domestic market and GDP, Tsai (1994) found these factors were the main determinants that attract FDI. These factors are significant variables that attract FDI inflows from the European Union (EU) to Central and Eastern European Countries (CEEC) (Tintin, 2013). In addition, Tintin (2013) finds that GDP size, institutional quality, and EU membership affect FDI inflows in these countries.

Villaverde and Maza (2014) suppose that FDI is driven by technology, labor, competitiveness, and economic variables by using 2000-2006 data. Kolstad and Wiig (2012) discover that FDI from China to the world is driven by market size, natural resources, and quality of institutions. The paper also groups these countries into OECD and non-OECD countries to find different factors affecting FDI.

\section{Model and data description}

In the gravity model, between two countries, the correlations of FDI with the market size, GDP, and GDP per capita are positive, but negative with distance. Many empirical studies support this model including Tinbergen (1962) and Pöyhönen (1963).

Similar to the gravity model, Portes et al. (2001) and Kolstad and Wiig (2012), this paper uses the variables:

$$
f d i_{i t}=\alpha_{i t}+\sum_{i=1}^{n} \beta_{i t} x_{i t}+\varepsilon_{i t}
$$


where $x_{i t}$ are independent variables including bilateral trade openness between China and European countries, gross domestic product of host countries, resources of host countries, inflation rate, and institutional quality of host countries.

The sources of our data are from the World Development Indicators, Coordinated Direct Investment Survey (CDIS) from IMF, and WGI. The contribution of this paper is the investigation in detail of bilateral data of Chinese FDI to Europe in 39 countries.

For the trade link between China and Europe, we use trade openness data including imports and exports of China and European-based partners from Trademap.

We use a panel dataset including China as a host country and 39 European home economies in 2009-2017. Bilateral FDI and other variables can be employed in disaggregated databases.

We use the "fdilog" as the dependent variable from China's direct investment net flows in logarithm to each European country (Tintin, 2013).

To avoid heteroskedasticity, autocorrelation, endogeneity issue ${ }^{1}$, and over-identification, we employ the two-step system generalized method of moments (GMM) in our models using lags of independent variables as instruments. Fisher unit root test based on the Dickey-Fuller test for unbalanced panel data find that the dataset is stationary.

Table 1. Summary of data description and sources.

\begin{tabular}{lll}
\hline \hline Variable & Definition & Source \\
\hline fdilog & & Logarithm of FDI from China to European countries \\
& Logarithm of imports and exports from China to & CPIS \\
tradelog & European countries & Trademap \\
resource & Total natural resources rents (\% of GDP) & WB WDI \\
inflat & Inflation, consumer prices (annual \%) & WB WDI \\
gdplog & Logarithm of GDP (USD) & WB WDI \\
voice & Voice and Accountability & WGI \\
political & Political Stability and Absence of Violence/Terrorism \\
goveff & Government Effectiveness & WGI \\
regul & Regulatory Quality & WGI \\
rule & Rule of Law & WGI \\
corrupt & Control of Corruption & WGI \\
\hline \hline
\end{tabular}

Sources: WB, IMF.

\section{Results}

Table 2 shows the descriptive statistics of our dataset. Some variable values are missing so the observations of them are different in numbers.

It is worth mentioning that the FDI flows from China to European countries exhibit the positive value. Meanwhile, the remaining six variables namely "voice," "political," "goveff," "regul," "rule," and "corrupt" represent the indices of institutional quality. In which, the higher values denote the socio-economic meanings from Table 1. For example, the high values of 'corrupt' demonstrate the level of controlling corruption. Moreover, Table 2 suggests that all variables exhibit abnormal distribution due to the skewed effects and kurtosis.

In Figures 2 and 3, the FDI flows complicated over 2009-2017. The FDI flows are highest in the Netherlands, Luxembourg, Kazakhstan, and the United Kingdom, but low and medium in the remaining countries.

\footnotetext{
${ }^{1}$ These test results are available upon request due to pages constraint.
} 
Table 2. Summary of descriptive statistics.

\begin{tabular}{lrrrrrr}
\hline \hline Variable & Obs & Mean & Std. Dev. & $\begin{array}{r}\mathbf{2 5}^{\text {th }} \\
\text { percentile }\end{array}$ & Median & $\begin{array}{r}\mathbf{7 5}^{\text {th }} \\
\text { percentile }\end{array}$ \\
\hline fdilog & 329 & 3.4980 & 0.3378 & 3.4338 & 3.4412 & 3.5034 \\
tradelog & 378 & 6.6673 & 0.7785 & 6.1154 & 6.7541 & 7.2353 \\
resource & 396 & 2.2980 & 5.2664 & 0.1556 & 0.5636 & 1.4194 \\
inflat & 396 & 2.8903 & 5.5634 & 0.3403 & 1.6240 & 3.4300 \\
gdplog & 396 & 11.1233 & 0.7653 & 10.5328 & 11.1911 & 11.6976 \\
voice & 387 & 0.6950 & 0.8413 & 0.1603 & 0.9981 & 1.3391 \\
political & 387 & 0.4467 & 0.7096 & 0.0008 & 0.6069 & 0.9768 \\
goveff & 387 & 0.7960 & 0.8283 & 0.1305 & 0.9048 & 1.5318 \\
regul & 387 & 0.8434 & 0.7460 & 0.2987 & 0.9685 & 1.4675 \\
rule & 387 & 0.7433 & 0.9211 & -0.1024 & 0.8850 & 1.6621 \\
corrupt & 387 & 0.6572 & 1.0340 & -0.1892 & 0.5539 & 1.6049 \\
\hline \hline
\end{tabular}

Notes: $* * *$ and $* * *$ show significance at the 10,5 and $1 \%$ levels, respectively.

Source: Authors' calculations

Table 3 shows that "tradelog"correlations with "fdilog" are positive and significant. This is because of the higher bilateral trade openness with China and higher Chinese FDI to Europe. This is similar with the theory that countries with higher trade openness will attract more FDI inflows (Dunning, 1976; Liargovas and Skandalis, 2012; Zhang and Daly, 2011). This finding is consistent with previous studies because the reduced information costs from home to host countries will promote FDI. Chinese investment flows focus on countries that have higher natural resource rents "resource," and the correlations between "fdilog" and resource are positive. Meanwhile, there are positive significant relationships between inflation and FDI flows, similar to Kolstad and Wiig (2012). Inflation is considered a proxy for macro stability; usually the increase of inflation will reduce FDI. But for China, perhaps the capital flows are seeking the instability of the macro-environment of European countries. "Gdplog" and "fdilog" have a negative relationship, which means that China is not seeking the scale of European countries' economy. This finding differs from the theory that GDP size will attract more investment because of the large market and scale will increase capital flows for market seeking. All institutional quality indicators have positive significant relationship with "fdilog". This echoes theories that the higher the quality of governance, the higher the FDI inflows (Kurul, 2017; Li et al., 2020; Tintin, 2013). Results differ from Kolstad and Wiig (2012) perhaps because of the different dataset of OECD and European countries.

To validate our regression models, we perform the first-order auto-regression for residual $(\mathrm{AR}(1))$ and second-order auto-regression for residual (AR(2)). The results indicated that our results are robust and reliable to interpret. Additionally, the Hansen test ensures that over-identifying restrictions in a statistical model is qualified. Our regression models passed all the necessary tests, implying that our previous findings are not spurious.

\section{Conclusions}

By using data between 2009 and 2017, this paper indicated the determinants of Chinese outward FDI in Europe in the disaggregated approach. The current literature indicates that FDI flows are driven by a recipient country's fundamentals. However, by employing a disaggregated panel dataset and an assortment of econometric techniques, our empirical results contribute the factors that affect Chinese outward FDI in Europe and direct investment.

Our study conveys some policy implications. To attract Chinese FDI, Europe could do several things. First, the improvement of institutional quality could be prioritized. Specifically, European governments should control corruption levels, amend and enhance the legal framework 
Figure 2. FDI from China to European Countries from 2009 to 2017 in World Map from our estimates.

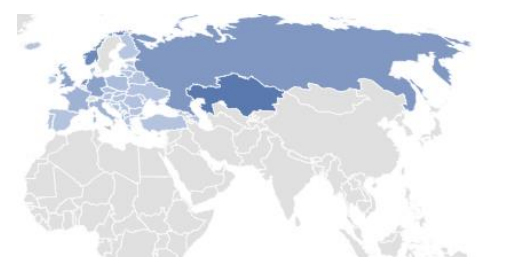

2009

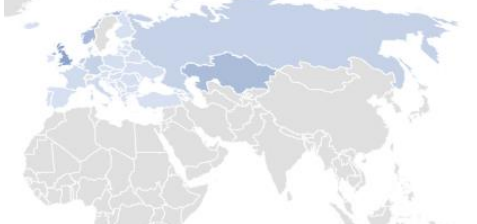

2012

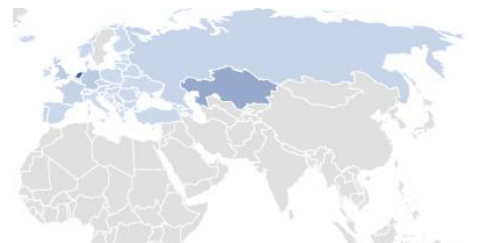

2015

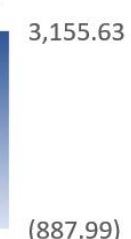

$20,612.25$

359.14)

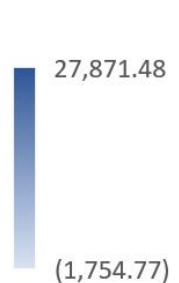

$(1,754.77)$

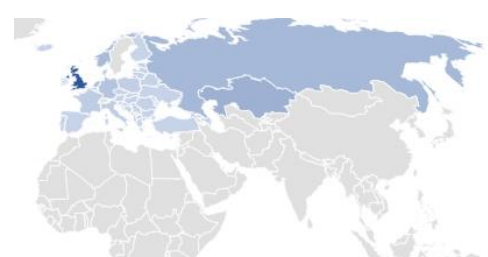

2010

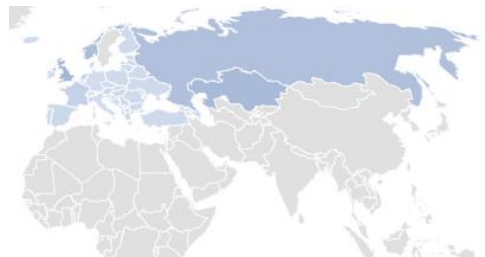

2013

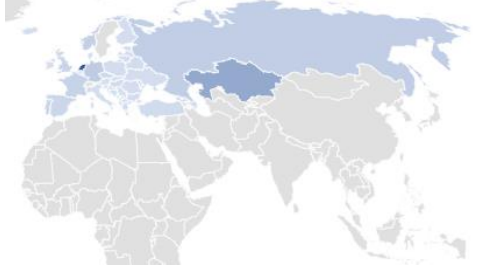

2016

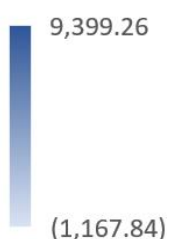

$(1,167.84)$

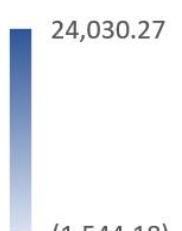

$(1,544.18)$

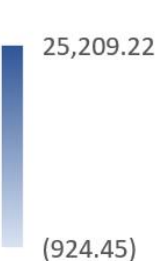

(924.45)

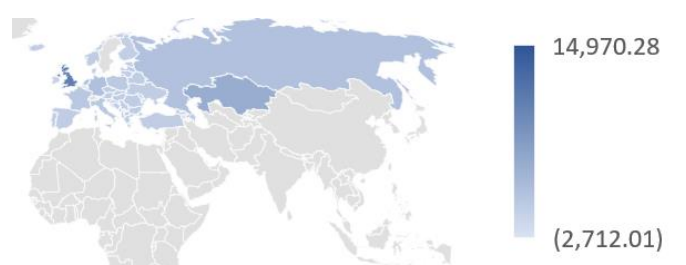

2011

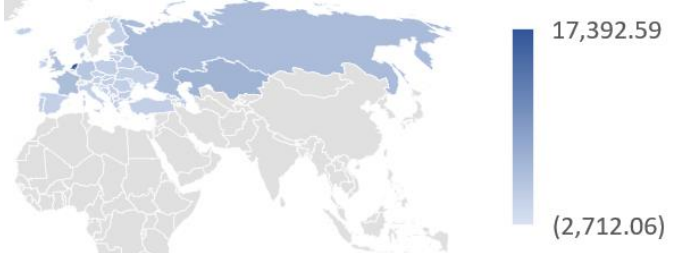

2014

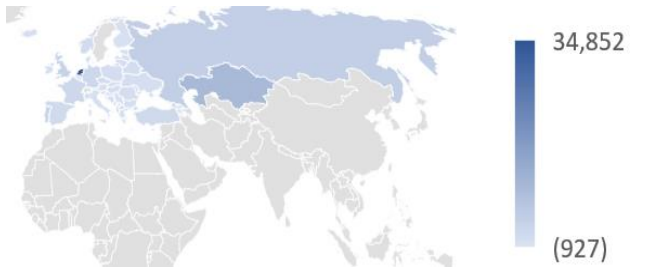

2017

Source: IMF Coordinated Direct Investment Survey - Visualization by the authors. 
Figure 3. FDI flows from China to European by countries.

Unit: Million USD

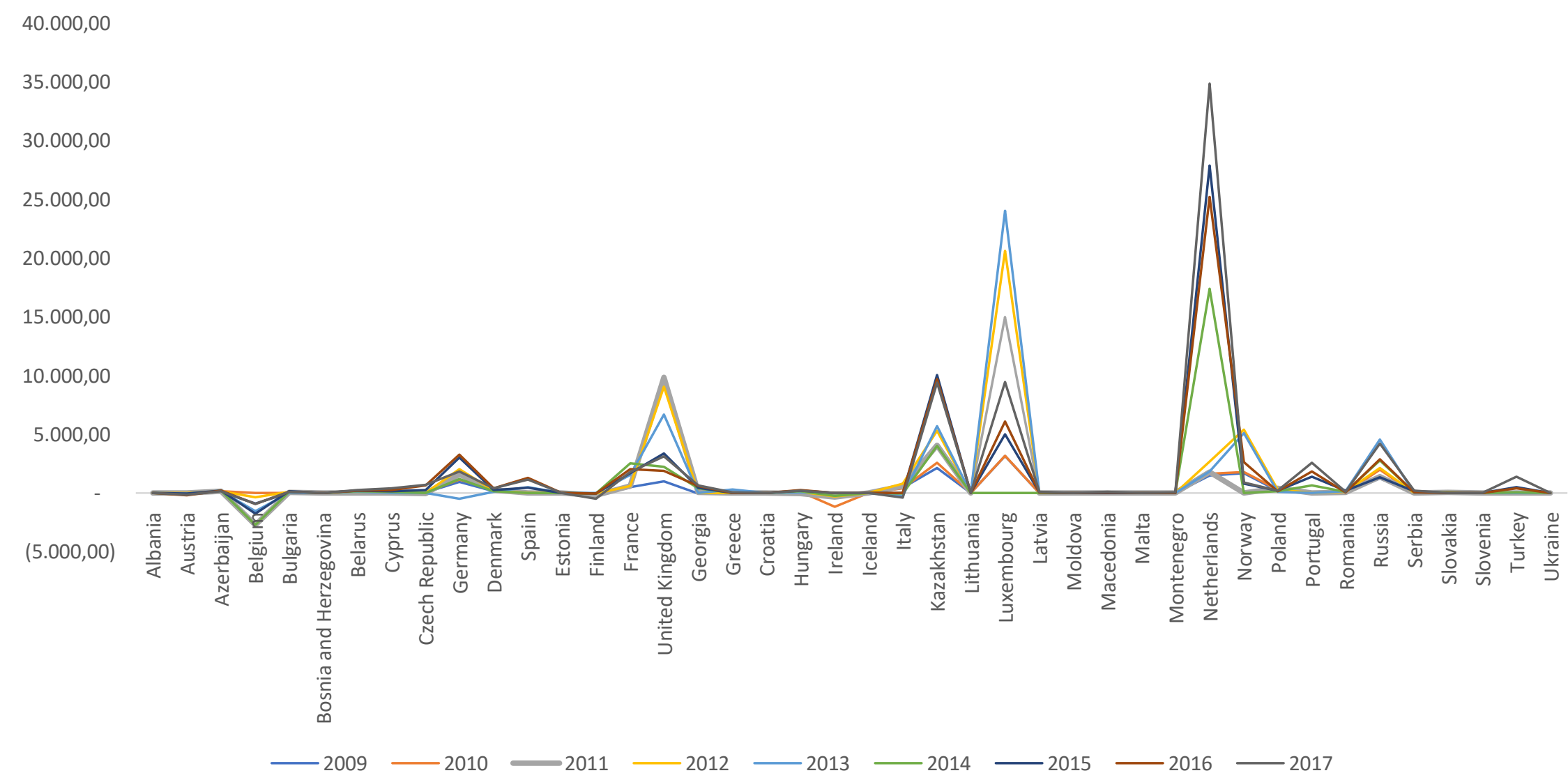


Table 3. System GMM regressions with six variables of institutional quality ${ }^{2}$.

\begin{tabular}{|c|c|c|c|c|c|c|}
\hline fdilog & (1) & $(2)$ & (3) & (4) & (5) & (6) \\
\hline & $0.231 * * *$ & $0.231 * * *$ & $0.228 * * *$ & $0.225 * * *$ & $0.228 * * *$ & $0.230 * * *$ \\
\hline \multirow[t]{2}{*}{ L.fdilog } & [0.001] & [0.001] & [0.001] & [0.001] & [0.001] & [0.001] \\
\hline & $0.097 * * *$ & $0.093 * * *$ & $0.077 * * *$ & $0.075^{* * *}$ & $0.076 * * *$ & $0.081 * * *$ \\
\hline \multirow[t]{2}{*}{ L.tradelog } & [0.008] & [0.008] & [0.011] & [0.011] & [0.013] & [0.014] \\
\hline & $0.007 * * *$ & $0.006 * * *$ & $0.008 * * *$ & $0.008 * * *$ & $0.008 * * *$ & $0.009 * * *$ \\
\hline \multirow[t]{2}{*}{ L.resource } & [0.001] & [0.001] & [0.001] & [0.001] & [0.001] & [0.001] \\
\hline & $0.001 *$ & 0.000 & $0.001 * * *$ & $0.001 * * *$ & $0.001 *$ & $0.001 *$ \\
\hline \multirow[t]{2}{*}{ L.inflat } & [0.000] & [0.000] & [0.000] & [0.000] & {$[0.001]$} & [0.000] \\
\hline & $-0.036 * * *$ & $-0.024 * *$ & $-0.026 * *$ & $-0.023 * *$ & $-0.025 *$ & $-0.031 * *$ \\
\hline \multirow[t]{2}{*}{ L.gdplog } & [0.009] & {$[0.010]$} & {$[0.011]$} & [0.011] & [0.013] & [0.014] \\
\hline & $0.024 * * *$ & & & & & \\
\hline \multirow[t]{2}{*}{ L.voice } & [0.005] & & & & & \\
\hline & & $0.022 * * *$ & & & & \\
\hline \multirow[t]{2}{*}{ L.political } & & [0.003] & & & & \\
\hline & & & $0.044 * * *$ & & & \\
\hline \multirow[t]{2}{*}{ L.goveff } & & & [0.004] & & & \\
\hline & & & & $0.042 * * *$ & & \\
\hline \multirow[t]{2}{*}{ L.regul } & & & & [0.006] & & \\
\hline & & & & & $0.040 * * *$ & \\
\hline \multirow[t]{2}{*}{ L.rule } & & & & & [0.007] & \\
\hline & & & & & & $0.042 * * *$ \\
\hline \multirow[t]{2}{*}{ L.corrupt } & & & & & & [0.005] \\
\hline & $2.427 * * *$ & $2.324 * * *$ & $2.443 * * *$ & & $2.452 * * *$ & $2.466 * * *$ \\
\hline Constant & [0.052] & [0.062] & [0.055] & & [0.063] & [0.072] \\
\hline Observations & 247 & 247 & 247 & 247 & 247 & 247 \\
\hline Number of id & 39 & 39 & 39 & 39 & 39 & 39 \\
\hline$A R(1)$ & 0.303 & 0.304 & 0.304 & 0.304 & 0.303 & 0.304 \\
\hline$A R(2)$ & 0.308 & 0.309 & 0.308 & 0.309 & 0.309 & 0.309 \\
\hline Hansen test & 0.126 & 0.161 & 0.145 & 0.146 & 0.167 & 0.128 \\
\hline
\end{tabular}

Notes: The dependent variable is 'fdilog'; standard errors are in parentheses. *, ** and *** show significance at the 10, 5 and $1 \%$ levels, respectively. Source: Authors' calculations.

${ }^{2}$ Six variables of institutional quality from World Governance Indicator are applied in six regression in table 4, respectively. Since, these six variables highly correlate with each other due to the high linear correlation values. In doing so, we would separate these institutional variables in individual model to avoid the perfect multicollinearity, leading to the spurious regression results. 
quality, stabilize the political status, and so on. Furthermore, European economies could scale up their economic status to gain more direct investment flows. More noticeably, controlling inflation is not as important as improving the scale of economy. Therefore, our study suggests that China is likely to seek for high inflation rates to dominate capital flows to Europe. These policy implications seem to contradict the extant literature about inflation and its role on economic growth (Nasir et al., 2020a; 2020b; 2020c; Pham et al., 2020). Our study is drawing the attention to the typical case of China for policymakers, who need to be cautious in implementing any investing strategies.

Because of the data availability from IMF CDIS, this study only examines the bilateral Chinese FDI and European countries in 8 years. Further research direction for Chinese capital flows should investigate specifically at firm-level data and specific industries.

\section{Acknowledgements}

This research is funded by University of Economics Ho Chi Minh City, Vietnam. This paper is based on part of first author's doctoral thesis at University of Economics Ho Chi Minh City. We are very grateful to Jonathan A. Batten, Nguyen Dong Phong, Ho Viet Tien and Vo Xuan Vinh for their helpful comments. Remaining errors are our responsibility.

\section{References}

Bellabona, P., \& Spigarelli, F. (2007). Moving from Open Door to Go Global: China goes on the world stage. International Journal of Chinese Culture and Management, 1(1), 93-107.

Blonigen, B. A. (2005). A Review of the Empirical Literature on FDI Determinants. Atlantic Economic Journal, 33(4), 383-403.

Buckley, P. J., Clegg, L. J., Cross, A. R., Liu, X., Voss, H., \& Zheng, P. (2007). The determinants of Chinese outward foreign direct investment. Journal of international business studies, 38(4), 499-518.

Choe, J. I. (2003). Do foreign direct investment and gross domestic investment promote economic growth? Review of Development Economics, 7(1), 44-57.

Dunning, J. H. (1976). Trade, location of economic activity and the MNE: A search for an eclectic approach: University of Reading, Department of Economics.

Dunning, J. H. (1993). Multinational Enterprises and the Global Economy. Addition-Wesley, Wokingham.

Egger, P., \& Pfaffermayr, M. (2004). Distance, trade and FDI: a Hausman-Taylor SUR approach. Journal of Applied Econometrics, 19(2), 227-246.

Faras, R. Y., \& Ghali, K. H. (2009). Foreign direct investment and economic growth: the case of the GCC countries. International Research Journal of finance and economics, 29, 134145.

Hanemann, T., \& Huotari, M. (2015). Chinese FDI in Europe and Germany: Preparing for a new era of Chinese capital. Mercator Institute for China Studies and Rhodium Group.

Kaufmann, D., Kraay, A., \& Mastruzzi, M. (2010). The worldwide governance indicators: A summary of methodology, data and analytical issues. World Bank Policy Research. Retrieved from

Kolstad, I., \& Wiig, A. (2012). What determines Chinese outward FDI? Journal of World Business, 47(1), 26-34.

Kurul, Z. (2017). Nonlinear relationship between institutional factors and FDI flows: Dynamic panel threshold analysis. International Review of Economics \& Finance, 48, 148-160.

Liargovas, P. G., \& Skandalis, K. S. (2012). Foreign direct investment and trade openness: The case of developing economies. Social indicators research, 106(2), 323-331. 
Li, C., Luo, Y., \& De Vita, G. (2020). Institutional difference and outward FDI: Evidence from China. Empirical Economics, 58(4), 1837-1862.

Lv, P., \& Spigarelli, F. (2015). The integration of Chinese and European renewable energy markets: The role of Chinese foreign direct investments. Energy Policy, 81(0), 14-26.

Lucas, R. E. (1990). Why doesn't capital flow from rich to poor countries?. The American economic review, 80(2), 92-96.

Markusen, J. R., \& Venables, A. J. (1998). Multinational firms and the new trade theory. Journal of international economics, 46(2), 183-203.

Mengistu, A. A., \& Adhikary, B. K. (2011). Does good governance matter for FDI inflows? Evidence from Asian economies. Asia Pacific business review, 17(3), 281-299.

Nair-Reichert, U., \& Weinhold, D. (2001). Causality Tests for Cross-Country Panels: a New Look at FDI and Economic Growth in Developing Countries. Oxford bulletin of economics and statistics, 63(2), 153-171.

Nasir, M. A., Balsalobre-Lorente, D., \& Huynh, T. L. D. (2020a). Anchoring inflation expectations in the face of oil shocks \& in the proximity of ZLB: A tale of two targeters. Energy Economics, 86, 104662.

Nasir, M. A., Huynh, T. L. D., \& Vo, X. V. (2020b). Exchange rate pass-through \& management of inflation expectations in a small open inflation targeting economy. International Review of Economics \& Finance.

Nasir, M. A., Huynh, T. L. D., \& Yarovaya, L. (2020c). Inflation targeting \& implications of oil shocks for inflation expectations in oil-importing and exporting economies: Evidence from three Nordic Kingdoms. International Review of Financial Analysis, 101558.

Pham, T. A. T., Nguyen, T. T., Nasir, M. A., \& Huynh, T. L. D. (2020). Exchange rate passthrough: A comparative analysis of inflation targeting \& non-targeting ASEAN-5 countries. The Quarterly Review of Economics and Finance.

Portes, R., Rey, H., \& Oh, Y. (2001). Information and capital flows: The determinants of transactions in financial assets. European economic review, 45(4-6), 783-796.

Pöyhönen, P. (1963). A tentative model for the volume of trade between countries. Weltwirtschaftliches Archiv, 93-100.

Tinbergen, J. (1962). Shaping the world economy; suggestions for an international economic policy.

Tintin, C. (2013). The determinants of foreign direct investment inflows in the Central and Eastern European Countries: The importance of institutions. Communist and PostCommunist Studies, 46(2), 287-298.

Tsai, P.-L. (1994). Determinants of foreign direct investment and its impact on economic growth. Journal of economic development, 19(1), 137-163.

Villaverde, J., \& Maza, A. (2014). The determinants of inward foreign direct investment: Evidence from the European regions. International Business Review.

Wang, C., Wei, Y., \& Liu, X. (2010). Determinants of bilateral trade flows in OECD countries: evidence from gravity panel data models. The World Economy, 33(7), 894-915.

Zhang, X., \& Daly, K. (2011). The determinants of China's outward foreign direct investment. Emerging Markets Review, 12(4), 389-398. 